\title{
EL CONCEPTO DE APLICACIÓN EN LA HERMENÉUTICA LITERARIA
}

\author{
Luis GALVÁN MORENO \\ Universidad de Navarra
}

Si Verdad y método de Hans-Georg Gadamer es una obra clave para la reflexión epistemológica y metodológica de las últimas décadas en los estudios literarios, como en las demás disciplinas humanísticas y sociales, resulta una paradoja que se haya abordado escasamente el concepto de aplicación; pues en Verdad y método se expone que la aplicación es un componente integral de toda comprensión y constituye «el problema central de la hermenéutica» (1984: 377-79, 414). Para Gadamer, «aplicación» es equivalente de «fusión de horizontes» (377), una acuñación bastante conocida; también la caracteriza como apertura y sumisión al sentido, a la validez y verdad que posee aquello que se trata de entender, sea una persona, una costumbre, un monumento, un texto transmitido (382-83): «uno tiene que dejar valer a la tradición en sus propias pretensiones [...] dejando que la tradición se convierta en experiencia y manteniéndose abiert[o] a la pretensión de verdad que le sale al encuentro desde ella» (438). 
Las exposiciones del pensamiento de Gadamer recogen, por supuesto, el concepto de aplicación, pero no siempre ponen de relieve la centralidad que él le atribuye ${ }^{1}$, o bien no lo elaboran de acuerdo con ella ${ }^{2}$. En reflexiones sobre hermenéutica literaria, es frecuente que la aplicación no sea tematizada, o que ideas similares se presenten sin referencia a la elaboración y las conclusiones de Gadamer ${ }^{3}$. En uno y otro ámbito se suele caracterizar la aplicación como fusión de horizontes ${ }^{4}$; sin embargo, para la literatura son más pertinentes las ideas de apertura y de verdad, como habrá ocasión de ver.

1 Por ejemplo, Bleicher dedica dos capítulos al pensamiento de Gadamer (II, 5 y 6), en los cuales sólo incidental y brevemente expone la fusión de horizontes y la aplicación (Bleicher, 1980: 111-12, 125-27). Outhwaite menciona la importancia de la fusión de horizontes (1985: 31,34), pero sólo usa el término «application» (27) para referir la opinión de Emilio Betti, según el cual Gadamer exagera su importancia. Weinsheimer ofrece «una lectura de Verdad y método» en forma de comentario lineal; la aplicación comparece en el lugar correspondiente (Weinsheimer, 1985: 184-87), pero no se aborda el puesto central que Gadamer le atribuye. Lo mismo sucede en Warnke (1987: 91-99), aunque recupera la cuestión, hasta cierto punto, en las conclusiones (168-71).

2 Por ejemplo, Madison (1991: 129) y Froman (1991: 145) destacan la centralidad de la aplicación, pero no la elaboran; ver también Grondin (1999: 167-70). Desde otra perspectiva, Betti ha notado la importancia de la aplicación en la hermenéutica gadameriana para enfrentarle sus objeciones (ver Betti, 1980, una traducción de su ensayo de 1962). Bruns presenta la aplicación de manera original, relacionándola con la catarsis trágica (1992: 179-94).

3 Por ejemplo, Lledó (1997: 55; el texto original es de 1985) recoge la idea de Gadamer de que la comprensión y la interpretación están intrínsecamente unidas, pero no menciona la aplicación. Cuesta Abad expone el pensamiento de Gadamer sin mencionar la aplicación (1991: 35-72), aunque alude a cuestiones relacionadas con ella en varios puntos (45, 47, 58); posteriormente aborda con independencia de Gadamer la cuestión de la verdad de los textos que se interpretan, y opta más bien por la teoría crítica, como hace también un trabajo posterior (Cuesta Abad, 1997: 9-29). Wahnón presenta la postura de Gadamer pero también opta por la crítica (1991: 103-09). Miller menciona en su introducción las cuestiones de la autoridad del texto, la pretensión de verdad y el diálogo en la hermenéutica de Gadamer (1999: 6); pero al abordar en un capítulo «le vrai sens caché» (27-34) atiende más al participio que al adjetivo antepuesto. Por otra parte, Szondi muestra cómo aparece el concepto de aplicación en la hermenéutica filológica anterior a Schleiermacher (Szondi, 1995: 33-41), aunque en la hermenéutica de Szondi hay poco lugar para él, pues lo que interesa es un método para interpretar los textos literarios (ver Szondi, 1978).

4 Bleicher define la aplicación como «the mediation of past and present» (1980: 126), es decir, fusión de horizontes; lo mismo hace Madison (1991: 130), quien además considera que la cuestión de la verdad no tiene lugar en el pensamiento de Gadamer (1991: 13233). Grondin relaciona la aplicación con el diálogo y con la apertura al texto (1999: 169- 
Ante el panorama descrito, este trabajo retorna en primer lugar a Verdad y método para analizar el sentido y las implicaciones del concepto de aplicación en la hermenéutica filosófica. En segundo lugar, se examinan las orientaciones para una hermenéutica específicamente literaria que Gadamer ofrece en su obra principal y en otros escritos de estética y poética, y los ejemplos que presenta en el comentario de algunos poetas. Por último, una sección conclusiva sopesa la validez y la parcialidad de esta hermenéutica literaria en la teoría y en la práctica, señala algunas cuestiones que deja abiertas y apunta ciertos desarrollos que estas han recibido y que pueden servir de base a una amplia agenda de estudios literarios.

\section{VERDAD, MÉTODO Y APLICACIÓN}

Hans-Georg Gadamer completa el giro ontológico y universal de la hermenéutica y pone en su centro, como se ha visto, la aplicación. El «estar ahí» («el ser que somos nosotros mismos», en palabras de Heidegger), «arrojado» en las vinculaciones concretas de costumbre y tradición y «proyectado» en las posibilidades de futuro, es, en la realización de su propio ser, comprender. El comprender es parte de la apertura al mundo; se trata de que se manifiesten los entes, «lo que es», y no de imponer las propias opiniones (Gadamer, 1984: 330-38). A la comprensión es inherente la verbalidad: ésta determina su objeto, pues lo que se entiende primariamente es texto, y determina también la ejecución de la hermenéutica, pues el que comprende trae a la expresión, en su propio lengua-

70), pero no llega a hablar de la pretensión de verdad y validez. En todo este contexto hay que destacar el trabajo de Hoy (1982), quien subraya y retoma varias veces el concepto de aplicación (51-55, 89-100, 166-68) relacionándolo tanto con la historicidad como con la verdad - por supuesto, el concepto mismo de verdad en la hermenéutica filosófica es problemático (ver, por ejemplo, Inciarte, 1986; Flamarique, 2002)_. En el campo de la literatura (aparte de ciertas hermenéuticas desarrolladas a partir de Gadamer, como la de Jauss y la de Ricœur, a quienes me referiré en las conclusiones), cabe destacar a Hernadi (1987), quien señala la aplicación como clave de los estudios literarios (con una breve alusión a Gadamer: 270); y las elaboraciones originales de Noakes (1988) y Weinsheimer (1991) a partir de la hermenéutica gadameriana, aunque la primera aborda escasamente la cuestión de la verdad (trata la aplicación, bajo el nombre de «interpretation», como actualización). 
je, la referencia del texto. Esto implica la unidad esencial de dos tareas de la hermenéutica clásica, la comprensión y la interpretación (1984: 46886). A ellas se une también esencialmente la tercera tarea, la aplicación, igualmente verbal porque el intérprete concreta el sentido haciendo una referencia a sí y a su mundo, a la vez que se deja guiar por lo que el texto dice (1984: 466-67, 477). En definitiva, la existencia se realiza en la comprensión, y todo comprender es aplicar.

El comprender tiene carácter de experiencia, que consiste en el paso de una negatividad a una positividad (1984: 430-39). Se descubre cómo lo que uno tiene por válido en general resulta no serlo frente a alguna instancia particular, y desde ahí se adquiere un nuevo saber más ajustado a la realidad. «La experiencia enseña a reconocer lo que es real» (1984: 433). La experiencia más propia del hombre es aquélla en que reconoce su finitud, los límites de lo que cabe esperar y planear para el futuro; es la experiencia de la historicidad y, al cabo, de la tradición. Ésta sólo se experimenta auténticamente cuando se acoge su pretensión de verdad, estando dispuesto a dejarse decir algo por ella, algo que puede concordar con las posiciones propias o contrariarlas.

Gadamer analiza la experiencia de lo bello y extiende sus características a la experiencia hermenéutica. Lo bello es esencialmente algo que se manifiesta de manera destacada y cautiva con su aparecer: se impone por sí mismo, convence de inmediato aun antes de encajar en el conjunto de las orientaciones y valores de quien lo experimenta; a partir de ahí, uno se plantea la tarea de integrarlo en ese todo. La experiencia hermenéutica es semejante, considera Gadamer, cuando acoge lo transmitido por la tradición en su legítima pretensión de validez, y toma parte así en el acontecer de un sentido y de una verdad (1984: 579-80). Uno es ganado para esa participación por lo bello o por lo transmitido en la tradición, incluso antes de que se plantee conscientemente el ponerlo a prueba o el resistirlo (1984: 585). Los métodos que posibilitan esto último son externos a la experiencia en que acontece la verdad, y por eso son insuficientes para garantizarla o regularla.

Pero las cuestiones de método no son indiferentes a la experiencia, porque pueden desvirtuarla. Ciertamente, Gadamer dice que basa Verdad y método en un análisis de la práctica fructífera de las disciplinas hermenéuticas, y que aspira a darles unos fundamentos más adecuados, no a cambiar sus procedimientos (1992: 252). No obstante, también declara 
que una nueva filosofía «mejor» podrá ayudar a la superación de errores prácticos y deformaciones. En particular, dos grandes formas de comprensión ponen la obra de arte y la tradición en peligro de quedar desposeídas de su pretensión de verdad: la conciencia estética y la conciencia histórica, sobre las cuales se vuelve una y otra vez en Verdad y método.

La conciencia estética, formada a lo largo del siglo XVIII, es aquélla que efectúa la diferenciación estética: separa de la obra de arte la finalidad, función, ocasión, contenido, y también la tradición que la transmite, es decir, todo lo relativo a su tema y su lugar en el mundo desde su origen hasta que llega al receptor; atiende sólo a factores formales, y se realiza en el momento de autoconciencia de la experiencia estética (Gadamer, 1984: 125-26). Gadamer examina las derivaciones de la conciencia estética hacia el subjetivismo de la experiencia estética que crea el mito de la genialidad del receptor (inversión del «genio creador» prerromántico), o la atomización de la obra en cada una de las vivencias estéticas a que da lugar (1984: 134-37). Bien pueden corresponder estas ideas, concede, a determinadas poéticas y a obras realizadas de acuerdo con ellas, y a aspectos de la experiencia del arte; pero es una carencia seria que no integren los pretendidos instantes de vivencia estética, separados y plenos, en la continuidad del existir humano. Esto sólo puede hacerse si se considera la recepción de arte como una experiencia con aspiración a la verdad (1984: 138-39).

La conciencia histórica recibe más atención en Verdad y método por haberse convertido durante el siglo XIX en el método científico por excelencia de las humanidades. Al considerar obras de arte y textos, la conciencia histórica sí toma en cuenta los contenidos y la conexión con el conjunto de una época, mas tampoco acoge su pretensión de verdad. Su objetivo es conocer el pasado como alteridad, en su individualidad y concreción; y encierra esa alteridad en el perímetro de los condicionamientos y determinaciones de la época pasada. De esa forma, la conciencia histórica deslegitima las aspiraciones de la tradición desde un punto de vista que considera más elevado y abarcador, se erige en un saber dominante y de ninguna manera pone en cuestión las propias posiciones y conocimientos a la luz de lo que llega a conocer del pasado (Gadamer, 1984: 437-38). Así, el filólogo y el historiador formados en la conciencia histórica distinguen metodológicamente entre el destinatario original de un texto y ellos mismos; se sustraen de su propia relación con el texto y se orientan a conocer opiniones o intenciones cuya verdad no se plantean o, en cualquier caso, no les 
afecta. Gadamer compara este proceder a una situación de examen, donde el examinador pretende exclusivamente descubrir la posición, capacidades, conocimientos del examinado, sin intención de saber aquello por lo que pregunta ni de llegar a un consenso (1984: 373).

Para comprender verdaderamente la tradición y enriquecerse con ella, explica Gadamer, no valen la conciencia «estética» ni la «histórica». Estas pretenden excluir la aplicación; y si aplicar es ineludible, porque pertenece intrínsecamente al comprender, el único resultado será que la aplicación suceda inconscientemente y como a las espaldas de quien comprende, y no ante sus ojos y de forma controlada. La advertencia y el control de la aplicación es lo propio de la «conciencia de la historia efectual», a la cual pertenece la tarea de recuperar la verdad de la tradición (Gadamer, 1984: 370-83, 414, 437-39).

Conciencia de la historia efectual es conciencia de la historicidad del comprender (Gadamer, 1984: 370-77)5. Consiste, en primer lugar, en que el intérprete tome conciencia de su propia situación, una tarea difícil porque en principio una situación no se aprehende temáticamente: es el desde dónde sale uno al encuentro de aquello que le transmiten. La situación se caracteriza por un horizonte: un límite de lo que se puede ver, con una orientación y un alcance dados, formado por los prejuicios del intérprete 6 .

5 Una de las acuñaciones clave de Verdad y método es la de «wirkungsgeschichtliches Bewusstsein», que se ha traducido como «conciencia de la historia efectual»o «de la historia de los efectos»; en ocasiones se vierte como «conciencia hermenéutica», de forma que queda alineada terminológicamente con la «conciencia estética» y la «histórica».

6 Estas consideraciones arrancan de la exposición de Heidegger sobre la «estructura del previo» (Vor-Struktur) del comprender, que se orienta por el «tener previo», tarea o intención (Vorhabe), el «ver previo» o atención (Vorsicht) y el «concebir previo» o anticipación (Vorgriff) (Heidegger, 1951/1976: § 32). A partir de ahí, Gadamer critica la depreciación del prejuicio en la Ilustración, presenta los prejuicios como condición de la comprensión, y defiende una rehabilitación de la autoridad y la tradición (1984: 338-53). Es sabido que esas ideas, con algunas formulaciones algo provocativas, han dado lugar al llamado «debate Habermas-Gadamer», entre otras discusiones con filósofos de la crítica de las ideologías; puede verse el volumen colectivo Hermeneutik und Ideologiekritik (Apel y otros, 1971; la réplica final de Gadamer está traducida en Gadamer (1992), y las exposiciones y valoraciones en Hoy (1982: 117-30) y en Nicholson (1991: 151-62). Según otra forma de afrontar el problema de la circularidad (Flamarique, 2002), el defecto del planteamiento gadameriano reside en poner como principio un conocimiento teórico y no un saber práctico, algo que estaba resuelto en la hermenéutica de Schleiermacher. 
En segundo lugar, ha de ganarse el horizonte histórico de las obras del pasado, es decir, los prejuicios y patrones a que respondieron aquellas originariamente. La adquisición del horizonte pasado es tarea que la conciencia histórica asumió como propia; ésa es su aportación al comprender. Garantiza el respeto de la alteridad del pasado, para que no sea nivelado ingenuamente con los prejuicios del intérprete actual. Sin embargo, no basta para un verdadero entender. De hecho, es un vicio señalado del método histórico el concebir el pasado como meramente ajeno ${ }^{7}$. Pues, además de la alteridad, se da una copertenencia de la obra transmitida y su intérprete. Aun cuando exista una gran distancia cronológica entre ellos, el pasado no es exclusivamente otro respecto del presente, sino que también está ahí en el presente, en la forma de tradición, es decir, en lo que se ha ido transmitiendo y precisamente como se ha ido transmitiendo. Gadamer concluye que no es exacto hablar de dos o más horizontes, los de tiempos pretéritos y el actual, sino de un solo horizonte que se mueve a lo largo de la vida y de la historia (1984: 374-75).

El horizonte es móvil porque está en continua formación gracias a experiencias: choque, pérdida y ganancia, como se ha expuesto antes. A esas experiencias pertenece por derecho propio el encuentro con el pasado en la tradición. Si uno mantiene la conciencia de su propia situación cuando se desplaza a horizontes históricos, permite que aquella sea afectada por la validez y la verdad que hacen frente desde el pasado: percibe la tensión entre lo que conoce del pasado y su presente, la aprehende sobre el fondo de los horizontes correspondientes, y lleva a cabo en fin la fusión de los horizontes. «Comprender es siempre el proceso de fusión de esos presuntos 'horizontes para sí mismos' (Gadamer, 1984: 376-77). El resultado de la conciencia de la historia efectual es «un ascenso hacia una generalidad superior»; una ampliación y profundización del presente en la continuidad de la tradición, donde «lo viejo y lo nuevo crecen siempre juntos hacia una validez llena de vida» (1984: 375, 377).

7 Según Gadamer, durante siglos se dio una aplicación o una sumisión ingenua a la tradición, que no es posible desde que surgieron el historicismo y la historiografía moderna; pero estos acontecimientos no han de desembocar fatalmente en que se despoje de todo poder la tradición (1992: 253-54). Si esto sucede es, como ya se ha dicho, porque se considera el pasado prisionero de su horizonte y sometido al horizonte más amplio y perfecto del presente. 
Así lo muestra el ejemplo de «lo clásico» (Gadamer, 1984: 353-60). El concepto de clásico ha sido convertido por la conciencia histórica (y en cierta medida por la estética) en una denominación de época y de estilo. Sin embargo, nació como concepto normativo, para señalar un modelo y un ideal en el arte, en la realización de los géneros literarios, etc. Durante siglos la normatividad fue asumida con pretendida inmediatez, hasta que la conciencia histórica relativizó lo clásico vinculándolo a determinadas condiciones de civilización. Después de la reflexión histórica no cabe la inmediatez, pero se puede mantener una normatividad que se haga cargo de la separación temporal y la diferencia entre aquel mundo y éste, tomando lo clásico como la presencia del pasado en el presente, al que ha llegado por una conservación continuamente confirmada. Comprender lo clásico es introducirse en el acontecer de esta tradición y de la verdad que presenta. De esta manera se efectúa una mediación de pasado y presente en que éste absorbe controladamente la alteridad del modelo clásico. Tal mediación, sugiere Gadamer (1984: 360), no es exclusiva ni especial de lo clásico; simplemente, en este caso sale a la luz con especial evidencia algo que pertenece a la esencia de la tradición.

Dar continuidad a la tradición es revitalizarla con nuevas miradas y nuevos sentidos, no meramente conservarla como un legado y someterse a dogmas recibidos. Gadamer señala las modificaciones del corpus y del concepto de lo clásico como parte de su vida histórica, según subrayó en respuesta a algunas críticas ${ }^{8}$. De manera semejante, expone que las sucesivas investigaciones sobre filosofía presocrática han procurado entender mejor «lo que se encontraba allí» gracias a nuevos prejuicios y poniendo en evidencia los prejuicios anteriormente aceptados (1992: 252-53). También con el cambio de las generaciones, las situaciones históricas, políticas y sociales y las ideas se ha mirado de manera renovada a los clásicos alemanes, Schiller, Goethe, Hölderlin (1993b: 39, 122, 128-29). Aunque Gadamer niega que la historia efectual deba ser una disciplina autónoma ni auxiliar de la investigación (1984: 370-71), está claro por estos ejemplos que el examen de la transmisión y de las tradiciones interpretativas permite un conocimiento más rico, desde diversas perspectivas, y ayuda a tomar conciencia de la propia situación y de la manera en que ésta ha sido formada también por el pasado transmitido.

\footnotetext{
8 Ver Gadamer (1992: 20), donde se refiere a críticas vertidas por Jauss (por ejemplo en 2000: 174-75; 1986: 23).
} 
Cada comprensión en que se funden los horizontes de pasado y presente se realiza en forma de diálogo, un intercambio de preguntas y respuestas (Gadamer, 1984: 447-58) ${ }^{9}$. Se inicia al dejar que el interlocutor plantee una pregunta; cuando se trata de una tradición o un texto transmitido, Gadamer habla de «ser afectado» por ellos. En estos casos, para responder, el intérprete a su vez tiene que preguntar, con el objetivo de entender lo dicho desde la tradición como respuesta a una pregunta propia de un horizonte histórico. Percibe entonces la existencia de un horizonte de preguntas que abarca tanto esa respuesta como otras posibles. Para entender algo como respuesta a una pregunta, es necesario entender la pregunta; y entender una pregunta propiamente como pregunta es, siempre, preguntarla: aceptar que señala algo cuestionable y que orienta hacia su resolución. Quien hace o admite una pregunta pone en suspenso opiniones y prejuicios, reconoce una ignorancia. Lo que se daba por cierto o no se planteaba queda ahora indeterminado y requiere respuesta. De otro lado, la formulación de la pregunta implica un límite para esa suspensión, aceptando que hay un punto de partida desde el cual es posible avanzar para responder (una falsa pregunta es la que no cuestiona verdaderamente nada, o la que presupone algo que no debiera). De esta manera, el horizonte histórico de preguntas revierte sobre la situación del intérprete afectado por la palabra de la tradición.

Admitida la pregunta, comienza el diálogo. Dialogar es someterse a la dirección de la cosa a la cual se orienta el diálogo (Gadamer, 1984: 43947). Consiste en sopesar la validez de cada argumento en relación con la cosa, no en refutar al contrario; en mirar su fortaleza, no su debilidad. Con el intercambio de preguntas y respuestas y el examen de opiniones se va construyendo un concepto en el cual, más allá de las creencias personales, la cosa misma de que se trata accede al lenguaje. Así pues, el diálogo presupone una cierta coincidencia lingüística, y sobre todo va formando una nueva lengua y una nueva comunidad fundadas en el acuerdo en torno al asunto. El acuerdo dialogado, escribe Gadamer, es una transformación

9 Agradezco a Pablo Rodríguez que haya llamado mi atención hacia la importancia del diálogo en Gadamer con su artículo «La actualidad filosófica de la hermenéutica» (que uso pro manuscripto); también le debo otras indicaciones para la comprensión del pensamiento gadameriano. Sobre lo dialógico en Gadamer, ver también Warnke (1987: 100-06; 16871) y Grondin (1999: 167-74). 
en algo común, de manera que uno ya no es lo mismo que era antes de empezar (1984: 458). En esto culmina la aplicación.

Una vez que se han visto los trazos fundamentales de la hermenéutica gadameriana, es el momento de una recapitulación antes de entrar en lo específicamente literario. Comprender, para Gadamer, es siempre aplicar. Lo que se comprende no es un mero objeto: porque llega al intérprete por medio de una tradición, está con él en una doble relación de alteridad y copertenencia, apunta a su estar ahí en una situación y le presenta una aspiración a la verdad. Para hacer justicia a una obra del pasado es necesario superar la conciencia estética que la despoja de contenido y función, y la conciencia histórica que la encierra en una época pretérita y pretende dominarla con métodos científicos de interpretación. Quien desea comprender debe dejarse afectar por la obra transmitida, preguntarle, descubrir un horizonte de preguntas al que responde y elaborar una nueva respuesta en común con ella. Esto exige una dialéctica de pregunta y respuesta ajustada a la cosa misma y a la situación en que se comprende. El resultado es un proceso en que el presente avanza y se amplía; en definitiva, una ganancia de verdad y libertad.

\section{APLICACIÓN EN LA HERMENÉUTICA LITERARIA}

Verdad y método contiene consideraciones sobre aspectos fundamentales de la literatura y su interpretación y sobre su lugar en una hermenéutica filosófica. Sin embargo, tales cuestiones son tan sólo vías de acceso al asunto esencial del libro, que es el proyecto de tal hermenéutica; por eso se tocan de pasada, y frecuentemente se amalgama la literatura ya con otras artes, ya con toda escritura (histórica, filosófica, religiosa, jurídica, etc.) ${ }^{10}$. Así pues, los fundamentos de una hermenéutica literaria planteados en la

10 Gadamer utiliza el término «Literatur» en el sentido de todo lo escrito, o en el específico de obras líricas, narrativas y dramáticas; en este segundo sentido utiliza también «Dichtung» y otros de la misma raíz. Cuando Gadamer escribe específicamente de literatura se refiere con frecuencia a lo que él considera literatura por excelencia, la poesía lírica, así es que «Literatur»y «Dichtung», «literatura» y «poesía»y sus derivados resultan intercambiables (ver por ejemplo 1993a: 286, y su traducción, 1998: 95). En las páginas que 
obra mayor de Gadamer ha de completarse con otros escritos, menores pero más desarrollados y concretos en lo que atañe a la literatura.

Verdad y método expone la particularidad de una interpretación de textos concebida, al igual que toda comprensión, en forma de diálogo (1984: 461-86). En este caso, uno de los interlocutores, el texto, no habla, sino que ha de darle voz el lector. Lo escrito permanece, es el dicho clásico: adquiere autonomía. Perdura más allá de las intenciones y de las circunstancias en que apareció; se destina a ser entendido en su pretensión de manifestar lo que realmente es, y no una mera opinión o vivencia de su autor, en relación con el cual hubiera de leerse siempre. Por otra parte, la autonomía de lo escrito conlleva una pérdida de substancia: se presenta como unas marcas despojadas de sentido. Recuérdese que el sentido, de acuerdo con Heidegger (1951/1976: § 32), no es una propiedad de las cosas sino un constituyente del existir humano como proyecto.

El lector es entonces quien puede efectuar «la reconversión de la huella de sentido muerta en un sentido vivo» (Gadamer, 1984: 216-17; ver también 472). El texto queda sometido necesariamente a la situación en que se comprende, pues sólo el horizonte, los pensamientos y conceptos del lector hacen posible la comprensión en que lo escrito accede una y otra vez a su verdadero ser, el sentido. Si esto parece una actualización ingenua por parte del lector, Gadamer puede contraponer el ejemplo de quien media como intérprete de una conversación en dos lenguas distintas: aunque parece estar en una posición superior porque domina las lenguas, en realidad su función es un servicio, facilitar que lo dicho en ellas dé lugar a una nueva situación de acuerdo (1984: 379). Quien lee debe permitir que hable el texto mismo, sin imponer los conceptos, que deben estar en suspenso, como en una pregunta. Se trata de la apertura a la alteridad y su pretensión de verdad: «dejar valer en mí algo contra mí, aunque no haya ningún otro que lo vaya a hacer valer contra mí» (1984: 438). Por eso la interpretación de textos es el paradigma de la hermenéutica: la situación del intérprete es el punto de partida insustituible y decisivo, y lo que se comprende es respetado y asumido. Su forma es el llamado «círculo hermenéutico»:

siguen evito usar «literatura» en el sentido más general ('escritos'), pero no siempre es posible —ni pertinente, como se verá— una distinción estricta entre «literatura» y «poesía». 
Tan pronto como aparece en el texto un primer sentido, el intérprete proyecta enseguida un sentido del todo. Naturalmente que el sentido sólo se manifiesta porque ya uno lee el texto desde determinadas expectativas relacionadas a su vez con algún sentido determinado. La comprensión de lo que pone en el texto consiste precisamente en la elaboración de este proyecto previo, que por supuesto tiene que ir siendo constantemente revisado en base a lo que vaya resultando conforme se avanza en la penetración del sentido

(Gadamer, 1984: 333).

La aplicación está, por tanto, ya en el comienzo de la lectura, y la acompaña hasta el final. La proyección primera se realiza desde lo que uno tiene por cierto y esperable, es decir, apuesta por una armonía entre el texto y su situación. Progresivamente irá corrigiendo sus anticipaciones de sentido, lo cual repercutirá, cuando sea necesario, en la situación que las fundamentaba.

Así pues, leer es una experiencia, un acontecer de la verdad que se descubre a partir de la propia posición y que puede modificarla. Estas consideraciones conectan con la crítica de la conciencia estética antes mencionada. La experiencia del arte es realmente experiencia que acontece en el mundo: en éste encontramos una obra de arte, y en ella un mundo, que se iluminan recíprocamente; al comprender la obra, nos comprendemos a nosotros mismos. Por eso, se puede hablar de un contenido de verdad en la experiencia del arte (Gadamer, 1984: 138-39), y es necesario hacerse cargo de su validez normativa, dejando que lo ejemplar funcione verdaderamente como tal. Gadamer aporta algunas calificaciones para la verdad de la literatura: es de un tipo específico, diverso, respecto de los demás textos (1984: 215-16); aún más, se encuentra en un orden superior: «Respecto a la tradición poética de los pueblos hay que reconocer que no admiramos en ella sólo la fuerza poética, la fantasía y el arte de la expresión, sino también y sobre todo la verdad superior que habla desde ella» (1984: 411) 11 .

11 Según escribe Gadamer en otro lugar, la existencia de una aspiración a la verdad en los textos literarios está reconocida por la tradicional queja de que «los poetas mienten», pues sólo se llama mentiroso al que dice lo falso con la intención de que se tome por verdadero (1993a: 70-71). 
Autonomía y verdad son los quicios de la hermenéutica literaria gadameriana. La poesía es especialmente autónoma respecto del entorno originario. Mientras lo que uno dice es, en general, respuesta a preguntas de su horizonte, y por tanto está en relación con un todo (que se pierde y ha de reconstruirse en el diálogo hermenéutico), la poesía absorbe esa relación y se presenta como autosuficiente. El acontecer verbal de la poesía enuncia una relación propia con el ser, sin necesidad de que se le añadan conocimientos ocasionales. No designa o copia un ente que ya existe, sino que abre un mundo, representa «el nuevo aspecto de un nuevo mundo» (Gadamer, 1984: 563). En consecuencia, su verdad es independiente de la relación con unos entes concretos en el mundo.

El texto también es autónomo respecto del autor. La lectura no trata de reproducir el acto mental pretérito que dio origen a lo escrito. Es más, Gadamer pone bajo sospecha el precepto hermenéutico de atenerse a los conocimientos del autor y al horizonte de sus destinatarios contemporáneos (1984: 474-75). ¿Qué es la contemporaneidad ante el carácter permanente de lo escrito? ¿En qué fecha termina la situación para la cual se escribió el texto: después de un día, de un año, de una década? Exegi monumentum aere perennius, sabía Horacio. Ante lo inestable de los límites temporales, la supuesta objetividad del criterio se esfuma. Además, ese precepto hermenéutico echa en olvido que el texto llega en una tradición, es decir, en copias y transmisiones, cada una de las cuales ha vuelto a referir el texto a nuevos contemporáneos. En definitiva, concluye Gadamer, vale más abandonar ese criterio limitador del posible sentido y liberar el texto para todas las referencias posibles en el presente.

La verdad de la poesía, autónoma respecto de referente y autor, reside en su lenguaje, según Gadamer. La invención poética consiste en hallar la lengua de cada poema, una vez que se han disuelto las palabras y formas de hablar habituales, expone citando a Hölderlin (Gadamer, 1984: 562-63). No es imprescindible un idioma selecto: las palabras más corrientes pueden ponerse en relación con la infinitud de las cosas no dichas, y dar así expresión a lo que nunca se ha dicho ni se volverá a decir (1984: 561); según escribe Gadamer en otro punto, el poema tiene la capacidad de suscitar una vida secreta en las palabras que parecen desgastadas e inservibles (1984: 539). Esto hace de la palabra poética «una prueba de lo que es verdad» (1984: 539). También es característico del lenguaje poético el que la «verdad» esté sostenida y garantizada por unas relaciones de orden (1984: 584), es decir, entramados o estructuras: tex- 
tos en sentido etimológico ${ }^{12}$. Como se ve, para Gadamer la noción de verdad es inherente a la de poesía y está vinculada con su lenguaje, sea el léxico o la disposición.

La referencia a unas relaciones de orden conduce al concepto de juego. El juego es transformación en una construcción o figura, y transformación en lo verdadero (Gadamer, 1984: 155-57). ¿Es la figura lo verdadero, más verdadera que lo figurado? Gadamer, siguiendo a Heidegger (1951/1976: $\S 44)$, considera la verdad como aletheia, sinceridad: el declarar uno lo que piensa y el manifestarse las cosas en su auténtico ser ${ }^{13}$. Pues bien, la vida real no posee tal aletheia en la medida en que es abierta, indecisa. No hay claridad en su manifestación, porque aparecen muchas posibilidades que se excluyen, líneas de sentido que se pierden en el vacío sin llegar a realizarse. En cambio, en el arte - Gadamer pone el ejemplo en especial del teatro, tragedia y comedia - se suprime ese aparente caos: se presenta un plexo, un círculo cerrado, en que todo tiene cumplimiento, sin posibilidades ni líneas abortadas carentes de significado. Así pues, el arte manifiesta más perfectamente la forma de la vida — uno habla de la tragedia o la comedia de la vida al percibir una forma, un orden en lo que sucede-. El arte es verdadero en este sentido de ser desvelador, y un encuentro con él tiene carácter de experiencia. «Lo que realmente se experimenta en una obra de arte [...] es más bien en qué medida es verdadera, esto es, hasta que punto uno conoce y reconoce en ella algo, y en este algo a sí mismo» (Gadamer, 1984: 158).

Verdad y método, en fin, plantea y suscita cuestiones fundamentales en torno a la poesía. Defiende su carácter de verdad, que reside en ella misma y no se mide por la relación con los entes del mundo ni por la intención

12 En este punto de Verdad y método Gadamer usa la expresión «Ordnungsbezüge» (1986: 493); en otros textos utiliza «Ordnungsgefüge» (por ejemplo 1993a: 49, 50). Sobre la constitución del texto: «Así como la palabra «texto» refiere, en realidad, al entrelazamiento de los hilos en un tejido que, por sí mismo, se mantiene unido y no deja que los hilos se salgan de su sitio, así también el texto poético es texto en el sentido de que sus elementos convergen en una palabra unificada y en una sucesión armoniosa de sonidos. Esta unidad constituye no sólo la unidad del sentido del discurso, sino también, con el mismo impulso, la de una configuración de sonidos» (1998: 101).

13 Gadamer utiliza el concepto y término de aletheia en 1984: 574-81; lo define y describe en otros textos posteriores (por ejemplo 1993a: 72-73; 1998: 17-18). 
del autor; considera que la manera de comprenderla es el diálogo, con la paradoja de que el texto «interlocutor» parece inaccesible porque es autosuficiente, habiendo absorbido el horizonte de preguntas. Y una lectura literaria de esa naturaleza constituye una experiencia de la obra y de uno mismo. Todos estos temas son retomados y perfilados en varios escritos breves de Gadamer sobre estética y poética.

Gadamer aborda y replantea en varios lugares la cuestión de la verdad de la poesía como aletheia. Siendo la poesía autónoma y ficcional, repite, no tendría sentido preguntarse por la adecuación a lo que piensa un hablante o al mundo exterior. Su verdad será la adecuación al ser del lenguaje: ¿se manifiesta en la poesía el lenguaje tal como es auténticamente, es decir, es verdadero lenguaje el suyo? Para Gadamer, lo es en grado extraordinario (1993a: 72-75; 1998: 43-44). El lenguaje de la poesía es lenguaje puro y pleno, y contiene todas las posibilidades de sus demás usos. Ilustra esa plenitud distinguiendo la poesía de otras dos manifestaciones eminentes del lenguaje: la religión y el derecho. En la religión, expone, el lenguaje es «promesa»(Zusage), y por tanto le es inherente la exigencia o la necesidad de que sea acogido por la otra parte. En el derecho, el lenguaje es «proclamación» (Ansage), pues las leyes sólo valen cuando aparecen públicamente y de manera correcta. En la poesía, es «declaración»o «enunciado»(Aussage), pura palabra sin más requisitos. Gadamer explica el prefijo Aus- en un sentido de 'perfección', 'totalidad'; y ésta como autorrealización sin remitir a ningún hecho ni ente ajeno al enunciado. El enunciado poético se basta en su propia presencia.

Al enunciado poético es inherente, como a todo lenguaje, un acontecer. Lo que se basta no es el «texto» como letra, sino el enunciado en el que se permanece o al que se vuelve con continuos actos de recitado, de lectura, de memoria (Gadamer, 1997). En esos actos ha de responderse a la pretensión de normatividad específica de la poesía. Corrientemente, los enunciados son pasos para un acuerdo; lo que importa es entenderlos y llegar al acuerdo, de modo que los pasos se dejan atrás. En cambio, la poesía nunca se queda atrás, sino que remite a un futuro acto de lenguaje en que se realizará su sentido pleno, aunque esto jamás llega a suceder de hecho. El lector no se da por contento con la comprensión alcanzada, sino que vuelve una y otra vez al texto, amplía y profundiza las relaciones de sonido y de sentido. Se deja introducir en el texto, «está en él» de manera inmediata —no lo 
«utiliza» como si fuera una herramienta que se toma y se deja según conviene-; descubre al final que cada palabra es insustituible por encajar en la estructura de sonido y sentido; es como si se hubiese fundado un nuevo lenguaje (Gadamer, 1997: 105-11). De acuerdo con esto, Gadamer examina en varios poemas el metro, el ritmo, la aliteración que hacen brillar palabras y expresiones de ordinario triviales. Por ejemplo, Eduard Mörike transforma un «scheint es», de un simple 'parece', a un 'resplandece', gracias a la aliteración y los acentos rítmicos en «Was aber schön ist, selig scheint es in ihm selbst» (Gadamer, 1997: 112-14); Stefan George da vida al término «Geräusch» por las aliteraciones en el verso «Und das Geräusch der ungeheuren See» (1998: 43). Leer así es cumplir la primera exigencia de la comprensión: el dejarse afectar por la palabra poética.

La segunda exigencia es comprender lo dicho como respuesta a una pregunta. ¿A qué responde un enunciado con tal aspiración de validez y permanencia, con tal libertad respecto del hablante originario y de su entorno? Gadamer avanza la idea de que ciertas obras literarias responden a grandes últimas preguntas de la humanidad: el nacimiento y la muerte, el dolor y la culpa; mas no ve posible que toda poesía sea siempre respuesta a tales cuestiones. La clave está en el ser de la poesía, la autorrealización, presencia y permanencia del lenguaje que es el poema en su acontecer (1993a: 77-78). Esto responde a la cuestión surgida de la constitución temporal del hombre, del carácter evasivo de las cosas y el contenido todo de la vida. El pasado se aleja, palidece y se difumina; genera así un déficit de presencia y actualidad. Frente a él, el enunciado poético se resiste a convertirse en pasado, se presenta siempre con inmediatez.

En este punto hay que volver a Verdad y método, donde Gadamer aborda el lenguaje y las lenguas como experiencia del mundo (1984: 526-47). Gadamer rechaza la distinción metódica entre la lengua como instrumento de comunicación y el contenido que accede a ella en la tradición y el diálogo. La lengua tiene su propio ser en la medida en que representa el mundo, y a la vez el mundo ha de acceder a la lengua. Gadamer (1984: 531-33) distingue entre el «mundo» del hombre y el «entorno» de los demás vivientes. Sólo el hombre puede poner ante sí lo que es tal como es, y comportarse libremente ante ello; y esto lo realiza de una manera verbal. La lengua custodia la inmediatez de nuestra visión del mundo y de nosotros mismos, y también la transforma mediante la 
reflexión, el diálogo y el encuentro con la tradición y con la poesía (1984: 539) ${ }^{14}$.

La poesía, al ponernos cara a cara con el lenguaje, lo muestra en la plenitud de sus posibilidades, en su cercanía al mundo y al hombre (Gadamer, 1993a: 78-79; 1998: 44-47). En la comunicación cotidiana el lenguaje se desgasta, las palabras pierden connotaciones, la mente se dirige a las cosas dejando atrás el texto. Asimismo, como queda dicho, las cosas y las experiencias se difuminan. Pero la poesía es puro lenguaje y presencia del lenguaje. Conserva la cercanía. No la de esto o aquello, la de algunas cosas cercanas a alguien, sino la cercanía como tal: el estar ahí, abierto al mundo, en el lenguaje; la familiaridad del mundo que se gana con una lengua. Esa familiaridad no es continuada ni fomentada por la poesía, sino que es tematizada por ella. El lector se detiene a mirarla, y es como mirarse en un espejo, porque es su familiaridad, en su lengua, con su mundo.

Además, el arte y la literatura instauran comunicación y comunidad. Para Gadamer, esto es inherente a la noción de belleza con que se ha definido el arte e incluso ha acompañado el término durante siglos ( «las bellas artes»). Desde la tradición griega, la belleza es manifestación, y por tanto tiene un reconocimiento público, colectivo (1991: 49); y en el pensamiento kantiano, un juicio estético aspira a la aprobación universal, a ser vinculante para todos, pese a que no puede imponerse con medios lógicos (1991: 57-58). El arte posee una dimensión colectiva, pretende englobar a todos, y de hecho puede experimentarse colectivamente, compartiendo una experiencia: «celebramos al congregarnos por algo y esto se hace especialmente claro en el caso de la experiencia artística. No se trata sólo de estar uno junto a otro como tal, sino de la intención que une a todos y les impide desintegrarse en diálogos sueltos o dispersarse en vivencias individuales» (1991: 101). Más allá del grupo unido ante una imagen o una representación teatral, la obra de arte también forma comunidad a partir de todos los individuos y conjuntos que la comprenden, dentro de una socie-

14 La traducción que utilizo, en este lugar, da: «la inmediatez [...] se guarda y se administra»; la cuarta edición revisada de Wahrheit und Methode da: «die Unmittelbarkeit [...] verwahrt und verwandelt ist» (1986: 453; cursivas mías). El párrafo anterior habla de las diferentes concepciones y formulaciones de la realidad, y en el párrafo siguiente aparece el término «Wandel» (esta vez sí traducido como «cambio»), por lo cual es preferible la interpretación que parafraseo arriba. 
dad e incluso a lo largo del tiempo y del sucederse las civilizaciones, como el Edipo rey aclamado en la Atenas clásica y en el Moscú posrevolucionario (1991: 119). Pero la comunidad no está siempre dada: construirla es una tarea en que las tradiciones se unen, se renuevan y se transmiten (11518); es decir, una tarea de la hermenéutica y de la aplicación.

Gadamer añade algunas consideraciones sobre la época contemporánea (1993b: 249-57; 1998: 107-09). Desde el siglo XVIII se han ido perdiendo las totalidades míticas, religiosas, históricas y políticas. Esto repercute en la verdad de la poesía. Ya no son posibles algunas formas literarias consagradas en la tradición que reposaban en semejantes totalidades, como la épica y la tragedia. La verdadera literatura contemporánea, creada por Proust, Joyce, Beckett, Musil, Celan, disuelve la acción, los personajes, el decurso temporal: su mensaje es una negativa, una recusación. De otra parte, en una situación como ésa, la experiencia de la poesía tiene un valor señalado. La lectura poética ofrece al hombre la posibilidad de entrar en un todo ordenado gracias a medidas, que asignan lo conveniente, de acuerdo con el ritmo, la articulación, el movimiento del verso. El lector de poesía descubre el valor del respeto de lo asignado, de las medidas que liberan y que permiten el acceso al todo. Este aprendizaje prepara para ingresar en la totalidad donde el hombre es, algo que también requiere respeto de la medida asignada. Y requiere memoria, la conservadora de cuanto somos en la tradición. Parte de esta es el poema, y permanecer en él rindiéndose a su fuerza vinculante es conservar la verdad del hombre y fundirse con ella, renovando continuamente, despertando y apropiándose una y otra vez una totalidad espiritual humana. La poesía educa para la humanidad.

En definitiva, la poesía enfrenta al hombre con su propio ser. Es encuentro con uno mismo, autoconocimiento y autocomprensión. Y como el encuentro se produce con la fuerza de lo bello, posee una evidencia que se impone. Tiene carácter de experiencia, de descubrimiento, y como tal exige de uno que reordene de acuerdo con la realidad aprehendida el conjunto de la relación con el mundo y de la comprensión de sí que tenía antes (Gadamer, 1993a: 6-8). Por eso Gadamer afirma que toda crítica de la poesía, que presupone el dejarse afectar por la palabra del poeta, es siempre autocrítica del intérprete (1993b: 280). O en otro punto (1993a: 8 ), para terminar con la cita de un poeta: junto al gozoso y temible sobresalto que descubre un «jasí eres tú!», hay un imperativo: «tienes que cambiar tu vida». 


\section{ALGUNOS EJEMPLOS}

El panorama de la hermenéutica gadameriana puede completarse con análisis de sus interpretaciones literarias. Gadamer dedicó bastante atención a la literatura, principalmente a poetas modernos, del clasicismo alemán en adelante; tal selección responde a sus ideas sobre la esencia de la literatura y también, sencillamente, a sus gustos. Esta es una ventaja del intérprete no profesional de literatura, y sin duda responde a la exigencia de «dejarse afectar» por el texto. En contrapartida, se produce un déficit de rigor: las concepciones literarias de Gadamer tienen en esos ensayos más bien ejemplos que pruebas para sentar una demostración de validez general.

Una primera tarea de sus interpretaciones es desembarazarse de cualquier referente extraliterario. Desestima ciertos estudios sobre el Burdeos que Hölderlin conoció y cantó en su poema «Andenken» (Gadamer, 1993b: 43-45); basta con la imaginación de cada uno, dice, igual que en el caso de la escalera de Los hermanos Karamazov de Dostoievski, imaginada por los lectores con seguridad, a pesar de la falta de datos (1993a: 75-76) —una de las escasas referencias de Gadamer a novelas-. Tampoco le parece procedente criticar las Elegías de Duino, de Rilke, en lo que atañe a la figura poética del ángel, con consideraciones de historia religiosa y de teología sobre los ángeles (1985: 449; 1993b: 273-74). En este último punto hace una precisión: la verdad de la poesía ha de comprenderse a partir de sus múltiples estratos, no directamente del material temático (1993b: 273). Evidentemente, Gadamer se atiene a la inmediatez de la palabra desligada de cualquier otro saber. Con ello renuncia a la elaboración de un horizonte histórico, a diferenciar entre el mundo en que surgió la obra con sus primeros lectores y el presente del intérprete. Trata el poema como puro enunciado.

Dejarse afectar y permanecer en el texto son exigencias de la lectura literaria ya comentadas. Gadamer se muestra sensible a los detalles de sonido y ritmo, como se ha mostrado con los ejemplos de Mörike y George. También presta atención y se deja guiar por las imágenes. En «Andenken» de Hölderlin observa cómo el soplo del viento mencionado en los primeros versos suscita el recuerdo en el hablante poético, quien recrea los barcos que partían del puerto de Burdeos con ese mismo viento, valora la actitud de recuerdo y esperanza de aquellas gentes, y conclu- 
ye el valor del recordar y por eso mismo de la poesía, que hace el recuerdo permanente, como enuncia el epifonema (1993b: 50-55). En el comentario de ocho versos de George observa la contraposición de orden humano y naturaleza que no admite límites; unas imágenes de luz al comienzo de cada serie le hacen notar que son dos aspectos sentidos por un mismo hablante, y que ese hablante simpatiza más con el orden pero se deja ganar por el infinito: por algo grande, más allá del hombre, y también por una alteridad que advierte dentro de sí (1993b: 245-48). En la poesía de Rilke explora lo que llama «una mitopoiesis del propio corazón» y la necesidad de una «inversión mitopoética» (1985). Las Elegías de Duino convierten los sentimientos en personajes y acciones, en trayectorias humanas, es decir, en nuevos mitos sui generis; el lector tiene que «invertir» esta «mitopoiesis» para entender los poemas; ahora bien, advierte Gadamer, la retraducción no ha de ser explícita en todo momento, porque enajenaría el texto convirtiéndolo en objeto de manipulación; el lector debe dejarse llevar por la mitopoiesis y obedecer el principio de la inversión, de manera que recupere el sentido de los poemas 15 . Así, Gadamer descubre en el ángel una representación de la infinitud y permanencia de los sentimientos frente a la limitación y la inconstancia propias del hombre; en el itinerario del muerto joven se recupera la sabiduría de las antiguas culturas y las tradiciones populares que lamentan pública y profundamente las muertes. Al final hay un aprendizaje de la finitud humana.

La importancia que da Gadamer a los finales corresponde a su valoración de la unidad de sentido: en ellos se alcanza la visión global. Las imágenes del avellano y de la lluvia al término de la décima elegía de Rilke sintetiza todas las experiencias acumuladas en el poemario de Duino y las lleva a un sentido completo, que reúne la limitación y la total entrega. Todo el comentario de «Andenken» se proyecta para hacer ver que el último verso — «Was bleibet aber, stiften die Dichter»— es coherente y muy significativo en relación con los recuerdos de Burdeos. Y la palabra última del poema de Mörike — «selbst»— es clave para provocar la resonancia interior y situar al lector en la contemplación de la belleza cuyo ser es brillar en sí. Y es que el texto poético no se deja atrás, sino que «nos quedamos dentro de él» (Gadamer, 1997: 111).

15 En la traducción «observar» el principio de la inversión (1985: 460) corresponde al original «befolgen» (1993b: 394), es decir, 'observar' como se observa una orden, una instrucción: obedeciéndola. 
Puesto que Gadamer encuentra en sus lecturas muchos de sus temas principales - la alteridad cultural en el espacio y en el tiempo, la permanencia de la palabra y en la palabra, la experiencia fundamental de la finitud humana-, no parecen surgirle problemas para admitir la pretensión de verdad que se le enfrenta. Sin embargo, en algún punto entabla un debate con el texto, y precisamente con uno de los que más lo atrajeron, las Elegías de Duino, de Rilke ${ }^{16}$. Gadamer recuerda que es necesario dejar valer lo que el poema dice, incluso contra uno mismo; es decir, la crítica de la poesía es autocrítica del intérprete (1993b: 279, 280). Por eso reprocha a Romano Guardini que haya opuesto a Rilke, interpretado en clave religiosa, las doctrinas de la teología ${ }^{17}$. Más bien habría que hacerse cargo, escribe, de la verdad que presentan las elegías y, si es posible, examinar los límites de esa verdad; se trata de juzgar el poema por lo que deja de decir. Así, encuentra en Rilke (Gadamer, 1993b: 280-81) unos conceptos del amor y de la muerte ligados a la limitación del hombre; el tú, como la muerte, es una barrera para el yo, y por eso escribe el poeta que el amor desemboca en la enemistad. Gadamer considera esto verdadero para muchas situaciones humanas, pero apostilla que Rilke nunca menciona el perdón y la reconciliación. Estos también son verdad, incluso la verdad más propia que recupera y eleva la libertad de los que aman; con ellos la persona es totalmente persona, no objeto ni obstáculo. En definitiva, las elegías presentan verdades que enseñan sobre el corazón humano, pero no son toda la verdad; es hacerles justicia el debatir con ellas en el terreno de uno, aceptarlas en cierta medida y contraponerles objeciones que encuentra en sí el propio intérprete. Este aprenderá también sobre sí mismo. Como escribe Gadamer en Verdad y método, lo destacado se destaca respecto de algo; lo uno y lo otro se ponen de manifiesto recíprocamente (1984: 376). Quien lee abriéndose a la pretensión de verdad no sólo gana experiencias transmitidas en el poema, sino también la experiencia de sí acontecida en el mismo leer.

16 Ver Gadamer (1993b: 271), con una síntesis de su prolongada atención a Rilke.

17 Gadamer se refiere al libro de Guardini Rainer Maria Rilkes Deutung des Daseins, original de 1953. Los reparos de Gadamer son de detalle; en general los dos autores comparten una visión fundamental de la poesía, y Gadamer considera que Guardini explica satisfactoriamente muchos aspectos de las Elegías de Duino. 


\section{CONCLUSIÓN, CRÍTICAS Y PERSPECTIVA}

Superpuestas al trasluz las tres secciones precedentes, se advierten las coincidencias fundamentales entre la hermenéutica filosófica de Gadamer, sus indicaciones para una hermenéutica literaria, y la práctica del comentario de poemas. La comprensión de la literatura acoge una pretensión de validez y verdad, la elabora en un diálogo que procura hacer justicia a todos los elementos del texto y llega a un acuerdo con el texto en torno a su asunto, que es de interés para el lector.

Hay, por otra parte, algunas divergencias señaladas entre la hermenéutica general de Gadamer y su interpretación de la poesía. En Verdad y método hay referencias a todos los géneros literarios, al teatro, a las sagas primitivas; en los escritos de Gadamer sobre estética y poética se mencionan novelas; pero las mayores precisiones y los comentarios se ciñen a la poesía lírica. Gadamer no plantea la necesidad de elaborar los horizontes históricos de las obras literarias, y de hecho no lo hace cuando se enfrenta con textos concretos; es más, descarta tal aproximación en el caso de Hölderlin, por ejemplo. Tampoco extrae un rendimiento interpretativo de la historia de los efectos de las obras que lee, ni siquiera la saca a la luz en todos los casos.

Antes de plantear una crítica basada en tales divergencias hay que advertir que no son arbitrarias. En cuanto a la primera, Gadamer es consciente de la parcialidad de su acercamiento al corpus literario, llama varias veces la atención sobre la centralidad de la poesía y sobre todo la poesía pura para la reflexión sobre el lenguaje y la hermenéutica, y orienta sus lecturas desde esa comunidad de intereses. Las otras dos divergencias, más de procedimiento, en parte tienen motivos circunstanciales. Tratándose de poetas modernos y contemporáneos, el horizonte de origen y la transmisión hasta el presente pueden darse por consabidos, o condensarse en pocas líneas, como hace Gadamer a veces. Pero además existe un motivo fundamental, la autonomía del texto poético. Si el poema no se refiere a nada fuera de sí, si tiene absorbidas y canceladas todas las referencias posibles y si no puede contrastarse con un mundo real, entonces no resulta pertinente elaborar el horizonte del pasado. Y si es pura presencia de su sentido, entonces las interpretaciones no son auténticas mediadoras entre el poema y el lector, y desde luego no dejan atrás el texto literario una vez que se han comprendido; así que el estudio de los 
comentarios y las transmisiones resultaría ser nada más que un rodeo. Gadamer escribe que el lenguaje se hace presente como «puro espíritu» y que la poesía puede comprenderse «sin [...] saberes ocasionales» (1984: $216,562)$, y así se enfrenta a sus textos.

Estas justificaciones no significan que Gadamer procediese de la única manera viable; a modo de crítica señalaré algunas cuestiones que quedaron abiertas, y luego se expondrá su desarrollo en la hermenéutica literaria de Hans Robert Jauss y en la de Paul Ricœur:

1. Gadamer admite que la autonomía de la obra literaria es variable según los géneros y tradiciones, y que hay diversidad de grados de referencia al mundo y de vinculación entre sonido y sentido (1998: 34-39, 105-07). Él se atuvo a los textos más autónomos, pero ¿cómo se enfrenta una hermenéutica literaria con obras en que las palabras representan entes, comportamientos, situaciones?

2. La diferencia de horizontes en el tiempo no puede pasar inadvertida; el propio Gadamer menciona las creencias en totalidades míticas, religiosas, etc. que durante siglos sostuvieron géneros como la épica y la tragedia, y la pérdida de tales creencias en la modernidad, caracterizada por una literatura de la desintegración y la recusación. ¿Qué función tiene esa diferencia de horizontes en la comprensión actual de la literatura de tiempos pasados?

En el horizonte, según Gadamer, hay preguntas a las que el texto responde. Gadamer señala una pregunta universal que brota de la caducidad del existir humano, pero también alude a preguntas concretas contestadas por obras concretas. ¿Qué papel tienen estas preguntas, y el horizonte que las contiene, en la comprensión?

3. Gadamer no estudia la historia efectual de las obras literarias, pero en el caso de la filosofía presocrática pone de relieve el papel descubridor de las distintas aproximaciones, y en general señaló a las disciplinas humanísticas la necesidad de hacerse conscientes de una historia efectual que, en cualquier caso, no iba a dejar de ejercer su poderío. ¿Cómo se incorpora la historia de los efectos a la comprensión de la literatura? 


\subsection{Autonomía y ficcionalidad de la literatura}

La aplicación de la ficción literaria es objeto de especial análisis por parte de Hans-Robert Jauss en su hermenéutica literaria, la estética de la recepción. Jauss propuso en su texto programático de 1967 restaurar y renovar la historia de la literatura abarcando las teorías del cambio literario inmanente de los formalistas rusos y la vinculación con la sociedad postulada por los teóricos del marxismo; el quicio había de ser la hermenéutica de Verdad y método (ver especialmente Jauss, 2000: 173-76). Precisando su relación con Gadamer, escribe:

sigo su principio de la aplicación y [...] entiendo la hermenéutica literaria como la tarea de interpretar la relación de tensión existente entre texto y presente como un proceso en el que el diálogo entre autor, lector y nuevo autor apura la distancia temporal, mediante el movimiento de ida y vuelta de pregunta y respuesta [...], concretizando el sentido siempre de una manera diferente $y$, por tanto, más rica

(Jauss, 1986: 23) 18 .

Jauss examina textos literarios de distintos géneros y épocas: lírica, drama y narrativa desde la Edad Media hasta el siglo XX. Por tanto, abarca obras que, sin dejar de ser fictivas y por tanto autónomas respecto del mundo real, tienen con éste una vinculación más estrecha que la lírica moderna comentada por Gadamer (un ejemplo que Jauss destaca inicialmente es Madame Bovary). Una obra de tales características no es mero lenguaje, sino representación de comportamientos posibles en el mundo, y al ser «acogida y juzgada [...] sobre el fondo [...] de la experiencia cotidiana de la vida», «puede hacer posible una nueva percepción de las cosas preformando el contenido de una experiencia que sale a la luz por vez primera en la forma de la literatura», liberando de prejuicios y tópicos y abriendo cuestiones que se daban por cerradas (Jauss, 2000: 185-93).

Tras esa primera aproximación, Jauss examinó componentes de la ficción como los héroes y personajes que despiertan la admiración, la compasión, la simpatía, la risa; otros géneros, como el teatro y la lírica (ver Jauss,

18 En las citas de Experiencia estética y hermenéutica literaria utilizo la traducción española (1986) pero introduzco leves modificaciones a la vista del original (ver Jauss, 1977: 18, 32). 
1986; 1989). En consecuencia, despliega un análisis de los elementos que hacen de la literatura una construcción ficcional y a la vez una experiencia comunicativa, y amplía el espectro de posibilidades de recepción:

La experiencia estética [...] nos lleva a otros mundos de la fantasía [...]; echa mano de experiencias futuras y abre el abanico de formas posibles de actuación; permite reconocer lo pasado o lo reprimido [...], posibilita tanto el característico distanciamiento de roles del espectador como la identificación lúdica con lo que él debe ser o le gustaría ser; permite saborear lo que, en la vida, es inalcanzable o lo que sería difícilmente soportable; ofrece un marco ejemplar de relaciones para situaciones y funciones, que pueden adoptarse mediante una mímesis espontánea o una imitación libre, y, por último, ofrece la posibilidad [...] de comprender la autorrealización como un proceso de formación estética

(Jauss, 1986: 40).

Crítica y denuncia de lo que existe, propuesta de alternativas y modelos, evasión y compensación son posibles resultados de la lectura literaria por el hecho de que la obra no reproduce un mundo que se encuentra fuera de ella, sino que conforma un mundo nuevo.

En este contexto es necesaria una referencia a Paul Ricœur, cuya concepción de la literatura ha acogido la hermenéutica gadameriana y la estética de la recepción y ofrece aportaciones personales que inciden en la cuestión de la verdad de la literatura y la aplicación. Ricœur ha elaborado el tema de la metáfora y el relato como fenómenos de innovación semántica con una peculiar forma de referencia. Entiende la metáfora como predicación a primera vista incoherente que el lector resuelve en una nueva coherencia; si por medio de enunciados veristas el mundo es descrito, ese mismo mundo es descubierto y redescrito por medio de la metáfora; esta es una manifestación del «ver-como», que responde al «ser-como» de las cosas (Ricœur, 1980; 1986: 18-25). En el relato, se parte de un mundo prefigurado (mimesis I), se configura un texto (mimesis II) y el lector de éste refigura el mundo de manera nueva (mimesis III); Ricœur ha identificado el refigurar con la aplicación hermenéutica, y lo ha elaborado de acuerdo con la estética de la recepción (1983-1985, vol. 1: 87-119; vol. 3: 228-63). En otro lugar, donde denomina «apropiación» la aplicación, ha precisado que no se trata de una congenialidad de autor y lector, ni de canonizar la lectura de los primeros receptores o destinatarios, ni tampoco de someter el texto a la capacidad finita del lector, sino de que el lec- 
tor «se abandone» en manos del texto para llegar con su ayuda a una autocomprensión más rica (Ricœur, 1981; ver también 1997: 131-33)19.

El «abandono de sí» del lector se relaciona con otro aspecto fundamental de la hermenéutica de Ricœur, su orientación metódica y objetiva. Ricœur propugna que se asegure el respeto al texto con un método riguroso, que él identifica con el estructuralismo. Con esto, por una parte, trae la hermenéutica a una situación filológica más moderna que aquella en que la planteó Gadamer; por otra, se ha atraído críticas de quienes ven una regresión hacia la linealidad y el objetivismo ${ }^{20}$. Parece que se propone analizar, explicar primero con el instrumental del estructuralismo, y después aplicar. Lo cierto es que la identificación de análisis estructural y objetividad no es tan rígida en la práctica. La posición de Ricœur es en realidad más abierta, como muestra el recorrido por teorías y críticos en los volúmenes de Temps et récit. Es un valor de su obra que plantee la cuestión de la verdad de la literatura y su relevancia para los lectores no al margen de los métodos, sino en diálogo con ellos.

\subsection{Horizontes de expectativas del pasado y experiencia literaria actual}

La estética de la recepción se constituye en una hermenéutica literaria de segundo grado cuando se propone estudiar la historia de la literatura como un proceso dialógico de textos y lectores inmersos en horizontes móviles a lo largo del tiempo (Jauss, 2000: 157-61). Se trata de conocer en qué horizonte aparece una obra y cómo la comprenden sus primeros lectores; cómo cambia el horizonte de éstos con motivo de la lectura; qué sucesivos cambios de horizonte afectan a la obra, sea para neutralizar su

19 Por eso Ricœur prefiere hablar de «espiral» o más frecuentemente de «arco» hermenéutico, en vez del círculo, para destacar que, si bien se parte del mundo del intérprete y se vuelve a él, ese mundo entretanto ha cambiado (1983: vol. 1, 111; 1986: 155, 158, 208, etc.; ver Balaguer, 2002: 151, 172).

20 Ver Hoy (1982: 89-90), aunque es una crítica algo prematura dada la cronología de la obra de Ricœur; ver también Bruns, (1992: 237-41). De acuerdo con Balaguer (2002: 133), Ricœur no plantea una secuenciación cronológica de comprensión y aplicación, sino una distinción epistemológica: primero se comprende, luego se aplica. Ver más adelante lo que se expone sobre la secuencia y distinción propuesta por Jauss (1981) — quien también valora la vinculación de estructuralismo y hermenéutica literaria (1981: 473-74)—. 
fuerza, sea para sacar a luz nuevos aspectos (171-81). Abarca además la posible incidencia de la lectura y el cambio de horizonte literario en las visiones del mundo, las proyecciones de modos de vida, etc., es decir, una aplicación que puede pasar de la conciencia hermenéutica a la praxis vital (185-93), de la manera que se ha apuntado en la sección anterior.

La estética de la recepción procura conocer los horizontes históricos con ayuda de los textos mismos que estudia y la investigación sobre su entorno. La obra literaria presenta indicaciones más o menos claras para la lectura, entre ellas alusiones a lo ya leído, a los géneros y convenciones consagrados; además de los indicios textuales, no siempre suficientes, se puede recurrir a orientaciones generales: a la poética del género a que pertenece, a las relaciones implícitas con obras del entorno histórico y literario, y a la diferencia entre ficción y realidad (Jauss, 2000: 164-66, 172). Jauss estima que el horizonte implicado por la obra es el menos problemático desde el punto de vista metodológico y que debe recibir en las investigaciones prioridad respecto del aportado por el lector perteneciente a una determinada sociedad (1986: 17; 1987: 78-80).

La investigación histórica del horizonte revierte en la lectura actual de la obra. Jauss ha distinguido metodológicamente los tres aspectos de la hermenéutica: comprender, explicar y aplicar. El primero tiene un carácter estético y general: percibe una coherencia formal y una plenitud de significación en la obra (Jauss, 1981: 474). Esta percepción se convierte en horizonte de la explicación, que elabora con más detalle una lectura del texto como respuesta a una determinada pregunta planteada por el lector (475); resulta más limitada que la comprensión, pero también más precisa. A partir de este punto es posible una lectura histórica, que descubra el texto como respuesta a preguntas del pasado, referentes a la forma y al sentido, que no coinciden con la pregunta contemporánea que le ha dirigido el intérprete (478). El resultado sirve de control, para que no se asimile ingenuamente el texto a las expectativas y preguntas del presente, y para que se realice una verdadera experiencia de comunicación con el pasado en la cual se contraste y se amplíe lo propio con lo ajeno (479). El conocimiento histórico, así, no se separa de la validez presente, como sería propio del historicismo, sino que la sustenta. Es otro camino, distinto y complementario de la explicación estructuralista propugnada por Ricœur, para asegurar metódicamente el respeto a la identidad de la obra, en medio de la variedad de comprensiones, con el convencimiento de que sirve a una lectura como acontecer de la verdad. 


\subsection{Historia de los efectos de las obras literarias}

La estética de la recepción considera la historia de los efectos de una obra como un despliegue enriquecedor de su potencial de sentido (Jauss, 2000: 159, 174; 1986: 23, citado arriba). El enriquecimiento ha de entenderse por la novedad y actualidad que recibe cada vez, no por una acumulación y superación de los sentidos anteriores en cada nueva lectura; pues, como ya se ha apuntado, Jauss señala que cada interpretación es limitada y discutible, y que su elaboración rigurosa siempre queda por debajo de la plenitud de sentido percibida estéticamente (1981: 478). Desde este punto de vista, la investigación del horizonte original encuentra un contrapeso en el estudio de la historia de la recepción: aquella orienta a un sentido determinado, este a una pluralidad de sentidos posibles. Además, la historia de la recepción tiene un valor crítico, pues hace ver las limitaciones de la propia lectura y la parcialidad de los prejuicios con los que uno la ha realizado ${ }^{21}$. Es una suerte de recurso a la comunidad interpretativa universal como referente de validación, de acuerdo con lo que propone Gadamer (1992: 253), ejemplificándolo con la historia de la investigación sobre filosofía presocrática, que ya se ha citado.

El despliegue del potencial de sentido resulta ser un ideal que no se cumple siempre. La obra puede ser rechazada por los lectores, que la encuentran difícil, y recuperarse sólo después de generaciones (Jauss ,2000: 169, 180); o bien puede ser enteramente asimilada: sucede con grandes obras innovadoras que llegan a convertirse en modelo, y desde la nueva situación, configurada en parte con ellas, deja de percibirse su fuerza (2000: 167-68). Jauss examina en este sentido el caso de la Ifigenia de Goethe. Habiéndose constatado la falta de interés de quienes la leen actualmente, se pregunta si el sentido original puede aún significar algo para el lector de hoy (Jauss, 1989: 218). La historia de la recepción revela que en un primer momento se habló de modernidad y audacia del drama; pronto se vio como representación de la Grecia histórica idealizada por el Neoclasicismo; después, como

21 Jauss no descarta utilizar la crítica ideológica como complemento de la hermenéutica, para desenmascarar ciertas interpretaciones; preferentemente, sin embargo, acepta su validez — «que se haga justicia al derecho histórico de aquellas concreciones que ya no constituyen una respuesta a intereses y cuestiones actuales» (1989: 244) — y considera la necesidad de que el intérprete critique su propia postura. 
un drama de la humanidad ideal; y por fin, como drama anímico propio de la esencia alemana (220-22). En este punto, la Ifigenia estaba totalmente asimilada a los tópicos en circulación y a la supuesta identidad colectiva de su público. Ahora bien, al contrastarla con la Ifigenia de Racine - para Goethe punto de referencia y a la vez modelo vitandose aclara a qué preguntas respondía. El drama de Racine expone los poderes que victimizan a los inocentes y deja que la nobleza de éstos condene aquéllos, pero no presenta una verdadera liberación. Goethe avanza el mito hacia la autonomía humana por medio de la pureza y la veracidad encarnadas en Ifigenia (234-35). Jauss ve aquí un sentido aún interesante y además abierto a nuevas preguntas, acerca de la relación de tal autonomía con los poderes políticos (que el drama deja de lado) y acerca del peligro de sustituir un mito preilustrado por uno ilustrado, sin salir de las mitificaciones (236-38). De acuerdo con este ejemplo, la historia de la recepción de una obra puede empobrecer su sentido y su carácter de respuesta, y la vuelta al horizonte original es lo que hace posible una nueva validez. También queda claro que la estética de la recepción se ocupa de preguntas más concretas que la derivada por Gadamer de la temporalidad humana.

A pesar de ejemplos como el anterior, la posibilidad de lecturas reductivas y de empobrecimiento a lo largo de la historia ha recibido poca atención por parte de la hermenéutica y de la estética de la recepción. Partiendo del optimismo de Gadamer, quien considera que un texto dará al traste con los prejuicios erróneos que se le traten de imponer (1984: 335), Jauss propone conocer el horizonte y la recepción de la obra primordialmente por medio del análisis del texto, como ya se ha señalado; para estudiar la historia de la recepción, considera que no es necesario detallar la totalidad de las interpretaciones, sino que bastan las más autorizadas (1994: 183). Sin embargo, estudios sobre casos particulares muestran lo frecuentemente que se asimilan las obras a los prejuicios del crítico e incluso se manipulan de acuerdo con ellos ${ }^{22}$. Además, en un trabajo

22 Ver por ejemplo Ehrismann (1975) y Von See (1991) sobre el Cantar de los Nibelungos; Mahal (1975) sobre Fausto de Goethe; Lobsien (1978) sobre Ulysses de Joyce; Banús (1996) sobre Herder; Gutiérrez (1999) sobre el Quijote; Galván y Banús (1999) sobre el Cantar de Mío Cid; Banús y Galván $(2000,2001)$ sobre el Cantar y sobre Tirso de Molina. 
sobre el Poema del Cid (Galván 2001) se constata la divergencia entre las interpretaciones presuntamente autorizadas, ejemplares, y las que tuvieron mayor difusión y por tanto podían ser más decisivas para configurar una recepción socialmente extendida. La divulgación marchaba con considerable retraso y ejercía una selección de las investigaciones, normalmente en el sentido de reducirlas a sus aspectos más tópicos; en consecuencia, la obra quedaba vulnerable a las manipulaciones de distinto signo que se produjeron desde finales del siglo XIX. Asimismo, se advierte que la copertenencia de obra y lectores y la aplicación fundada en ella puede ser una construcción de las interpretaciones divulgadas. Durante décadas se concedió en prólogos, reseñas, libros de texto, etc., un valor ejemplar al Poema del Cid en la idea de que representaba la esencia de lo nacional castellano y español, a la vez que se reconocía - por voz de intérpretes tan señalados como Menéndez Pelayo y Menéndez Pidalque lo nacional no estaba expreso en ningún punto del texto, sino que lo descubrían los lectores en el conjunto; lectores, claro está, entrenados en la escuela y otras formas de mediación para usar la categoría de lo «nacional» en la comprensión de las obras. De acuerdo con estos datos, la estética de la recepción no puede evadirse de una exigencia de examinar con exhaustividad la tradición escrita - grandes interpretaciones, prólogos, manuales, reseñas, alusiones en distintos contextos- e incluso la no escrita -marco institucional, formas de publicación (formato, colecciones) y distribución, etc. - si quiere conocer la situación hermenéutica en que se han recibido las obras y la función formadora de sociedad que han ejercido23.

En conclusión, una hermenéutica centrada en el concepto de aplicación proporciona al estudio de la literatura orientaciones para un pluralismo abierto a la verdad de las obras. Abarca una variedad de métodos a la vez que señala la insuficiencia de cualquiera para acceder al pleno sentido de un texto; legitima el acceso desde prejuicios históricamente condicionados y desde preguntas orientadas por ellos, a la vez que advierte la necesidad de modificarlos de acuerdo con lo que se lee. El objetivo es realizar lecturas verdaderas, descubridoras: que dejen manifestarse la obra, y que

23 Una parecida exigencia de exhaustividad fue descubierta por la Literatura Comparada para su propio campo (Trousson, 1965: 23-32, 62-71) y planteada a la estética de la recepción por un comparatista (Chévrel, 1980). 
ante ella descubran al lector para sí mismo y lo renueven. Todo esto es muy distinto de una crítica informal, espontánea, diletante, subjetiva, relativista: exige un análisis detallado del texto con toda su potencia verbal e imaginativa, una investigación del horizonte y las preguntas a que respondió originariamente, y de las tradiciones que lo han transmitido hasta la actualidad, enriqueciéndolo o al contrario; y de esa manera el intérprete no elude sino que fundamenta su participación personal en el acontecer de sentido y verdad y en la comunidad que se instaura en torno a ellos.

\section{REFERENCIAS BIBLIOGRÁFICAS}

Apel, K. O., Habermas, J., Gadamer, H. G., y otros (1971). Hermeneutik und Ideologiekritik. Frankfurt a.M.: Suhrkamp.

BAlaguer, V. (2002). La interpretación de la narración: la teoría de Paul Ricœur. Pamplona: Eunsa.

BANÚs, E. (1996). Untersuchungen zur Rezeption Johann Gottfried Herders in der Komparatistik: Ein Beitrag zur Fachgeschichte. Bern: Lang.

Banús, E. y Galván, L (2000). «De cómo Mio Cid viajó a Alemania y volvió a España. La recepción de una recepción». La Corónica 28.2, 21-49.

— (2001). «La recepción del humor de Tirso de Molina: prejuicios y autoridades». En Actas del V Coloquio Internacional de la Asociación Internacional Siglo de Oro (Münster 1999), Ch. Strosetzki (ed.), 161175. Madrid: Iberoamericana - Frankfurt a. M.: Vervuert.

BetTI, E. (1980). «Hermeneutics as the General Methodology of the Geisteswissenschaften». En Contemporary Hermeneutics: Hermeneutics as Method, Philosophy and Critique, J. Bleicher (ed.), 51-94. London: Routledge \& Kegan Paul.

Bleicher, J. (1980). Contemporary Hermeneutics: Hermeneutics as Method, Philosophy and Critique. London: Routledge \& Kegan Paul.

Bruns, G. L. (1992). Hermeneutics Ancient \& Modern. New Haven London: Yale University Press. 
Cuesta Abad, J. M. (1991). Teoría hermenéutica y literatura (el sujeto del texto). Madrid: Visor.

- (1997). Las formas del sentido: estudios de poética y hermenéutica. Madrid: Ediciones UAM.

ChÉvrel, Y. (1980). «L'étude de l'opinion en histoire littéraire: le dilemme quantitatif / qualitatif». En Literary Communication and Reception: Proceedings of the IXth Congress of the International Comparative Literature Association, Z. Konstatinovic, M. Naumann y H. R. Jauss (eds.), vol. 2: 129-33. Innsbruck: Universität.

Ehrismann, O. (1975). Das Nibelungenlied in Deutschland: Studien zur Rezeption des Nibelungenliedes von der Mitte des 18. Jahrhunderts bis zum ersten Weltkrieg. München: Fink.

FlamARiQue, L. (2002). «Reflexiones sobre la naturaleza filosófica de la hermenéutica». Thémata: Revista de filosofía 28, 215-33.

Froman, W. J. (1991). «L'Écriture and Philosophical Hermeneutics». En Gadamer and Hermeneutics, H. J. Silverman (ed.), 136-148. New York - London: Routledge.

GAdAMER, H. G. (1984). Verdad y método: fundamentos de una hermenéutica filosófica. Salamanca: Sígueme.

- (1985). «La inversión mitopoética en las Elegías de Duino, de Rilke». En Métodos de estudio de la obra literaria, J. M. Díez Borque (coord.), 445-461. Madrid: Taurus.

- (1986). Wahrheit und Methode: Grundzüge einer philosophischen Hermeneutik (Gesammelte Werke, 1). Tübingen: J. C. B. Mohr.

- (1991). La actualidad de lo bello: el arte como juego, símbolo y fiesta. Barcelona: Paidós.

- (1992). Verdad y método II. Salamanca: Sígueme.

- (1993a). Ästhetik und Poetik I: Kunst als Aussage (Gesammelte Werke, 8). Tübingen: J. C. B. Mohr.

— (1993b). Ästhetik und Poetik II: Hermeneutik im Vollzug (Gesammelte Werke, 9). Tübingen: J. C. B. Mohr.

- (1997). «Texto e interpretación». En Hermenéutica, J. Domínguez Caparrós (ed.), 77-114. Madrid: Arco/Libros. 
- (1998). Arte y verdad de la palabra. Barcelona: Paidós.

Galván, L. (2001). El «Poema del Cid» en España, 1779-1936: recepción, mediación, historia de la filología. Pamplona: Eunsa.

- y BAnús, E. (1999). ««Seco y latoso» - «Viejo y venerable»»: El Poema del Cid a principios del siglo XX o del cambio en la apreciación de la literatura». Rilce 15, 115-40.

GRONDIN, J. (1999). Introducción a la hermenéutica filosófica. Barcelona: Herder.

GuARDini, R. (1966). Rainer Maria Rilkes Deutung des Daseins: Eine Interpretation der Duineser Elegien. Mainz: Matthias Grünewald Paderborn: Ferdinand Schöningh.

GutiÉRrez, C. M. (1999). «Cervantes, un proyecto de modernidad para el Fin de Siglo (1880-1905)». Cervantes 10, 113-24.

Heidegger, M. (1951). El ser y el tiempo. México - Buenos Aires: FCE.

- (1976). Sein und Zeit. Frankfurt a. M.: Vittorio Klostermann.

HeRnADI, P. (1987). «Literary Interpretation and the Rhetoric of the Human Sciences». En The Rhetoric of the Human Sciences, J. S. Nelson, A. Megill y D. N. McCloskey (eds.), 263-75. Madison: The University of Winsconsin Press.

Hoy, D. C. (1982). The Critical Circle: Literature, History and Philosophical Hermeneutics. Berkeley: University of California Press.

INCIARTE, F. (1986) «Hermenéutica y sistemas filosóficos». En Biblia y hermenéutica: VII simposio internacional de teología de la Universidad de Navarra, J. M. Casciaro, G. Aranda, J. Chapa y J. M. Zumaquero (eds.), 89-101. Pamplona: Eunsa.

JAUSS, H. R. (1977). Ästhetische Erfahrung und literarische Hermeneutik. München: Fink.

- (1981). «Zur Abgrenzung und Bestimmung einer literarischen Hermeneutik». En Poetik und Hermeneutik. Arbeitsergebnisse einer Forschungsgruppe IX: Text und Applikation. M. Fuhrmann, H. R. Jauss y W. Pannenberg (eds.), 459-81. München: Fink.

- (1986). Experiencia estética y hermenéutica literaria. Madrid: Taurus. 
- (1987). «El lector como instancia de una nueva historia de la literatura». En Estética de la recepción, J. A. Mayoral (ed.), 59-85. Madrid: Arco/Libros.

- (1989). «La Ifigenia de Goethe y la de Racine. Con un epílogo sobre el carácter parcial de la estética de la recepción». En Estética de la recepción, R. Warning (ed.), 217-50. Madrid: Visor.

- (2000). La historia de la literatura como provocación. Barcelona: Península.

Lledó, E. (1997). «Literatura y crítica filosófica». En Hermenéutica, J. Domínguez Caparrós (ed.), 21-57. Madrid: Arco/Libros.

LobsiEn, E. (1978). «Die rezeptionsgeschichtliche These von der Entfaltung des Sinnpotentials». Rezeptionsgeschichte oder Wirkungsästhetik: Konstanzer Diskussionsbeiträge zur Praxis der Literaturgeschichtsschreibung, H. D. Weber (ed.), 11-28. Stuttgart: Klett-Cotta.

Madison, G. B. (1991). «Beyond Seriousness and Frivolity: A Gadamerian Response to Deconstruction». En Gadamer and Hermeneutics, H. J. Silverman (ed.), 119-135. New York - London: Routledge.

MAHAL, G. (1975). «Der tausendjährige Faust: Rezeption als Anmaßung». En Literatur und Leser: Theorien und Modelle zur Rezeption literarischer Werke, G. Grimm (ed.), 181-95. Stuttgart: Reclam.

Miller, R. A. (1999). Hermès et Aminadab: Essai d'herméneutique littéraire. Toronto: Paratexte.

Nicholson, G. (1991). «Answers to Critical Theory». En Gadamer and Hermeneutics, H. J. Silverman (ed.), 151-162. New York - London: Routledge.

NOAKES, S. (1988). Timely Reading: Between Exegesis and Interpretation. Ithaca - London: Cornell University Press.

Outhwaite, W. (1985). «Hans-Georg Gadamer». En The Return of Grand Theory in the Human Sciences, Q. Skinner (ed.), 21-39. Cambridge: Cambridge University Press.

RICEUR, P. (1980). La metáfora viva. Madrid: Europa.

- (1981). «Appropiation». En Paul Ricour: Hermeneutics and the Human Sciences: Essays on Language, Action and Interpretation, J. B. 
Thompson (ed. y trad.), 182-93. Cambridge - London - New York: Cambridge University Press - Paris: Éditions de la Maison des Sciences de l'Homme.

- (1983-1985). Temps et récit, 3 vols. Paris: Seuil.

- (1986). Du texte à l'action: Essais d'hermeneutique, II. Paris: Seuil.

- (1997). «La función hermenéutica del distanciamiento». En Hermenéutica, J. Domínguez Caparrós (ed.), 115-133. Madrid: Arco/Libros.

Szondi, P. (1978). «Über philologische Erkenntnis». En Peter Szondi: Schriften, J. Bollack (ed.), vol. 1: 263-86. Frankfurt a. M.: Suhrkamp.

- (1995). Introduction to Literary Hermeneutics, M. Woodmansee (trad.). Cambridge - New York: Cambridge University Press.

Trousson, R. (1965). Un Problème de la littérature comparée: Les études des thèmes: essai de méthodologie. Paris: Lettres Modernes.

Von SeE, K. (1991). «Das Nibelungenlied - ein Nationalepos?». En Das Nibelungenlied: Ein deutscher Wahn, ein deutscher Alptraum: Studien und Dokumente zur Rezeption des Nibelungenstoffs im 19. und 20. Jahrhundert, J. Heinzle y A. Waldschmidt (eds.), 43-110. Frankfurt a. M.: Suhrkamp.

WARnke, G. (1987). Gadamer: Hermeneutics, Tradition, and Reason. Cambridge: Polity Press.

WeInSHEIMER, J. (1985). Gadamer's Hermeneutics: A Reading of «Truth and Method». New Haven (Conn.): Yale University Press.

- (1991). Philosophical Hermeneutics and Literary Theory. New Haven (Conn.) - London: Yale University Press.

Wahnón Bensusan, S. (1991). Saber literario y hermenéutica: en defensa de la interpretación. Granada: Universidad. 